\title{
PENTINGNYA BUDAYA KESELAMATAN PASIEN DI RUMAH SAKIT
}

\author{
NISFU \\ Nisfuaraman11@gmail.com
}

\section{LATAR BELAKANG}

Dewasa ini keselamatan pasien menjadi isu penting yang diperbincangkan secara global. Keselamatan pasien menjadi komposisi penting dalam terciptanya pusat layanan kesehatan yang bermutu dan berkualitas. Keselamatan pasien perlu dijadikan sebagai suatu budaya di dalam pusat layanan kesehatan seperti rumah sakit sehingga penerapannya dapat terjadi secara spontan tanpa paksaan. Menurut Depkes RI (2008) Keselamatan pasien (patient safety) rumah sakit adalah suatu sistem dimana rumah sakit membuat asuhan pasien lebih aman. Sistem tersebut meliputi:

\section{a. Assessmen risiko}

b. Identifikasi dan pengelolaan hal yang berhubungan dengan risiko pasien

c. Pelaporan dan analisis insiden

d.Kemampuan belajar dari insiden dan tindaklanjutnya serta implementasi solusi untuk meminimalkan timbulnya risiko.

Sistem tersebut diharapkan dapat mencegah terjadinya cedera yang disebabkan oleh kesalahan akibat melaksanakan suatu tindakan atau tidak melakukan tindakan yang seharusnya dilakukan.Standar pelayanan rumah sakit, telah diterapkan pada sistem manajemen mutu iso, dan lain-lainnya, yang mana dapat meningkatkan kualitas pelayanan rumah sakit dilihat dari aspek struktur, pada prosesnya dan juga pada hasilnya. kenyataanya masih terdapat kejadian yang tidak diharapkan (ktd) sehingga masyarakat merasa tidak puas dan terjadi tuntutan hokum. oleh karena itu diperlukan penerapan budaya keselamatan pasien di setiap pusat layanan kesehatan seperti rumah sakit untuk mencegah terjadiya hal yang tidak diinginka. 
Menurut fleming (2006) dalam hamdani (2007), budaya keselamatan pasien yaitu suatu jalan untuk menciptakan program keselamatan dengan cara focus pada pelaksanaan programnya sehingga dapat menghasilkan keselamatan pasien.

\section{METODE}

Metode yang digunakan adalah metode pengkajian, dimana penulis mengkaji beberapa literature yang bersumber dari beberapa jurnal dan juga artikel terpercaya. Setelah penulis mengkaji maka selanjutnya penulis akan memaparkan hasil pengkajiannya dalam tulisan ini.

\section{TUJUAN}

Tujuan dari penulisan ini adalah untuk memberikan informasi mengenai pentingnya penerapan budaya keselamatan pasien sehingga dapat mengurangi angka kejadian yang tidak diinginkan yang terjadi kepada pasien. Selain untuk mengurangi kejadian yang idak diinginkan, oenulisan ini juga bertujuan untuk meningkatkan derajat kesehatan bagi setiap orang.

\section{HASIL}

Dari pengkajian ini diperoleh hasil bahwasanya penerapan budaya keselamatan pasien merupakan hal yang sangat penting untuk diterapkan pada setiap intansi pusat layanan kesehatan seperti salah satunya rumah sakit, hal ini disebabkan karena budaya keselamatan pasien yaitu suatu jalan untuk menciptakan program keselamatan dengan cara focus pada pelaksanaan programnya sehingga dapat menghasilkan keselamatan pasien. Salah satu tujuan dari keselamatan pasien yaitu menurunnya KTD yang merupakan bagian dari insiden keselamatan pasien. Untuk mencapai tujuan tersebut, maka dicipakanlah budaya Keselamatan pasien yang bertujuan mendorong perbaikan spesifik dalam keselamatan pasien. Selain itu, Budaya keselamatan pasien merupakan faktor yang paling penting dalam upaya untuk mengurangi resiko yang merugikan di rumah sakit dan meningkatkan keselamatan pasien. Budaya keselamatan pasien merupakan kompsisi penting dalam pelayanan kesehatan dan telah dikaitkan dengan hasil pasien yang diperoleh pasien di rumah sakit. Sebuah penelitian mengungkapkan bahwa keberhasilan pelaksanaan program keselamatan pasien oleh petugas rumah sakit dipengaruhi oleh beberapa hal, salah satu nya adalah budaya keselamatan pasien. Saat ini sudah banyak 
penelitian mengenai budaya keselamatan pasien dan pengaruhnya terhadap pelaksaan program keselamatan pasien

\section{PEMBAHASAN}

\section{Budaya Keselamatan Pasien}

Dewasa ini keselamatan pasien menjadi isu penting yang diperbincangkan secara global. Keselamatan pasien menjadi komposisi penting dalam terciptanya pusat layanan kesehatan yang bermutu dan berkualitas.

Keselamatan pasien merupakan prinsip dasar dalam pelayanan kesehatan. Menurut Depkes RI (2008) Keselamatan pasien (patient safety) rumah sakit merupakan suatu sistem dimana rumah sakit mampu memberikan asuhan pasien lebih aman. Sistem tersebut meliputi:
a. assessmen risiko,
b. identifikasi dan pengelolaan hal yang berhubungan dengan risiko pasien,
c. pelaporan dan analisis insiden,
d. kemampuan belajar dari insiden
e. tindaklanjutnya serta implementasi solusi untuk meminimalkan timbulnya risiko. Sistem tersebut diharapkan dapat mencegah terjadinya cedera yang disebabkan oleh kesalahan akibat melaksanakan suatu tindakan atau tidak melakukan tindakan yang seharusnya dilakukan.

Sasaran kselamatan pasien menyoroti bagian-bagian yang bermasalah dalam pelayanan kesehatan dan menjelaskan bukti serta solusi dari konsensus berbasis bukti dan keahlian atas permasalahan yang ada. Penyusunan sasaran ini mengacu kepada Nine Life-Saving Patient Safety Solutions dari WHO Patient Safety (2007) yang digunakan juga oleh Komite Keselamatan Pasien Rumah Sakit PERSI (KKPRS PERSI), dan dari Joint Commission International (JCI). Jika rumah sakit ingin menurunkan kejadian insiden keselamatan pasien maka rumah sakit harus menerapkan budaya keselamatan pasien. Sampai saat ini, banyak negara telah memulai penelitian budaya keselamatan pasien, baik Negara maju maupun Negara berkembang seperti Indonesia. Penelitian tentang budaya keselamatan pasien telah berkembang dalam beberapa 
tahun terakhir. Namun, masih kurang evaluasi objektif dan kuantitatif dari kualitas penelitianpenelitian tersebut.

Keselamatan pasien ini dapat diraih dengan menciptakan budaya keselamatan pasien di suatu rumah sakit sebagai pusat layanan kesehatan.

Menurut fleming (2006) dalam hamdani (2007), budaya keselamatan pasien yaitu suatu jalan untuk menciptakan program keselamatan dengan cara focus pada pelaksanaan programnya sehingga dapat menghasilkan keselamatan pasien. Salah satu tujuan dari keselamatan pasien yaitu menurunnya KTD yang merupakan bagian dari insiden keselamatan pasien. Untuk mencapai tujuan tersebut, maka dicipakanlah budaya Keselamatan pasien yang bertujuan mendorong perbaikan spesifik dalam keselamatan pasien. permintaan masyarakat untuk perawatan yang lebih aman telah memberikan dampak terhadap industri kesehatan untuk memahami hubungan antara keselamatan pasien dan kinerja rumah sakit. penelitian brown \& wolosin (2013) mencoba memaparkan hubungan antara persepsi staf terhadap budaya keselamatan dan langkah-langkah yang sedang berlangsung di rumah sakit berdasarkan struktur unit keperawatan, proses perawatan, dan resiko yang merugikan pasien. hubungan antara tindakan keperawatan, kinerja rumah sakit dan budaya keselamatan dieksplorasi di 9 rumah sakit california dan 37 unit keperawatan. persepsi i budaya keselamatan diukur 6 bulan sebelum pengumpulan metrik keperawatan dan hubungan antara kedua data yang dieksplorasi menggunakan hubungan korelasional dan analisis regresi. hubungan signifikan yang ditemukan adalah langkah-langkah proses untuk pencegahan jatuh. beberapa asosiasi diidentifikasi dari budaya keselamatan dan struktur pemberian perawatan, seperti campuran keterampilan, pergantian staf, dan intensitas beban kerja menunjukkan hubungan yang signifikan dengan budaya keselamatan. budaya keselamatan merupakan faktor penting untuk memahami upaya untuk memajukan perawatan pasien yang aman. hasil ini memberikan implikasi kualitas pelayanan untuk kepemimpinan rumah sakit. ketika para pemimpin memprioritaskan budaya keselamatan, resiko terhadap pasien mungkin telah diperbaiki dengan pergantian staf dan peningkatan produktivitas. hal ini dapat dijadikan investasi dalam sistem keselamatan pasien untuk memberikan perawatan andal dan aman (brown \& wolosin, 2013). 


\section{Pentingnya Budaya Keselamatan Pasien di Rumah Sakit}

Budaya keselamatan pasien merupakan faktor yang paling penting dalam upaya untuk mengurangi resiko yang merugikan di rumah sakit dan meningkatkan keselamatan pasien. Budaya keselamatan pasien merupakan kompsisi penting dalam pelayanan kesehatan dan telah dikaitkan dengan hasil pasien yang diperoleh pasien di rumah sakit. Sebuah penelitian mengungkapkan bahwa keberhasilan pelaksanaan program keselamatan pasien oleh petugas rumah sakit dipengaruhi oleh beberapa hal, salah satu nya adalah budaya keselamatan pasien. Saat ini sudah banyak penelitian mengenai budaya keselamatan pasien dan pengaruhnya terhadap pelaksaan program keselamatan pasien. Walshe dan Boalden (2006) dalam Hamdani (2007) menyatakan bahwa penyebab utama kesalahan medis karena kesalahan sistem di rumah bukan karena kesalahan individu (NPSA, 2004) Manfaat penting dari budaya keselamatan pasien antara lain:

a. Kesalahan yang telah terjadi lebih dapat diketahui oleh suatu organisasi kesehatan

b. Meningkatkan pelaporan insiden dan belajar dari insiden yang terjadi untuk mengurangi berulangnya dan kecelakaan yang terjad

c. Adanya kesadaran terhadap keselamatan pasien dengan cara mengurangi kecelakaan secara fisik dan psikis

d. Mengurangi biaya pengobatan dan ekstra terapi.

e. Mengurangi sumber daya untuk manajemen komplain dan klaim.

Menurut Reason (1997) dalam Hamdani (2007) budaya keselamatan terdiri dari empat komponen (subculture) yaitu: 1) Informed culture. Budaya dimana pihak yang mengatur dan mengoperasikan sistem memiliki pengetahuan terkini tentang faktor-faktor yang menjelaskan keselamatan dalam suatu sistem. 2) Reporting culture. Budaya dimana anggota di dalamnya siap untuk melaporkan kesalahan atau near miss. Pada budaya ini organisasi dapat belajar dari pengalaman sebelumnya. Konsekuensinya makin baik reporting culture maka laporan kejadian akan semakin meningkat Just culture.3) Budaya membawa atmofer trust sehingga anggota bersedia dan memiliki motivasi untuk memberikan data dan informasi serta sensitif terhadap perilaku yang ada. Termasuk di dalamnya lingkungan non punitive (no blame culture) bila staf 
melakukan kesalahan. Penting bagi setiap level di organisasi untuk bersikap jujur dan terbuka. 4) Learning culture. Budaya dimana setiap anggota mampu dan bersedia untuk menggali pengetahuan dari pengalaman dan data yang diperoleh serta kesediaan untuk mengimplementasikan perubahan dan perbaikan yang berkesinambungan (continous improvement). Learning culture merupakan budaya belajar dari insiden dan near miss. Survei Hospital Survey On Patient Safety Culture menngukur budaya keselamatan pasien dari segi perspektif staf rumah sakit. Survei ini dapat mengukur budaya keselamatan pasien untuk seluruh staf rumah sakit dari housekeeping, bagian keamanan dari dokter sampai perawat.

Dari penjelasan di atas terpapar jelas mengenai bagaimana pentingnya penerapan budaya keselamatan pasien di rumah sakit. Penerapan ini tidak hanya berguna untuk meningkatkan mutu dari suatu rumah sakit akan tetapi juga menjadi dasar terjaganya kondisi pasien sehingga mampu meningkatkan derajat keehatan.

\section{KESIMPULAN}

Budaya keselamatan pasien merupakan hal yang sangat penting untuk diterapkan pada setiap intansi pusat layanan kesehatan seperti salah satunya rumah sakit, hal ini disebabkan karena budaya keselamatan pasien yaitu suatu jalan untuk menciptakan program keselamatan dengan cara focus pada pelaksanaan programnya sehingga dapat menghasilkan keselamatan pasien. Budaya keselamatan pasien merupakan faktor yang paling penting dalam upaya untuk mengurangi resiko yang merugikan di rumah sakit dan meningkatkan keselamatan pasien. Budaya keselamatan pasien merupakan kompsisi penting dalam pelayanan kesehatan dan telah dikaitkan dengan hasil pasien yang diperoleh pasien di rumah sakit.

\section{DAFTAR PUSTAKA}

Afrisya, I. (2014). Analisis Budaya Organisasi dan Budaya Keselamatan Pasien Sebagai Langkah Pengembangan Keselamatan Pasien di RSIA Budi Kemuliaan Tahun 2014. Jurnal arsi. Vol 1. Hal 19-200

Anwar, Z. (2018). Mentoring sebagai suatu inovasi dalam peningkatan kinerja. Jurnal of Education and Instruction, 1(1), 21-28.

Brown, D. S., \& Wolosin, R. (2013). SafetyCulture Relationships with HospitalNursing 
Sensitive Metrics. Journal for Healthcare Quality, 61-74.

Depkes RI. (2008). Panduan NasionalKeselamatan Pasien Rumah Sakit(Patient Safety): Utamakan Keselamatan Pasien. Jakarta: Depkes

RI.

Essy, M, Hardisman, \& Husna, Y. (2018). Analisis Dimensi Budaya Keselamatan Pasien Oleh Petugas Kesehatan di RSUD dr Rasidin Padang Tahun 2018. Jurnal fk unand.

Najihah.(2018). Budaya keselamatan pasien dan insiden keselamatan pasien di rumah sakit: literature review. Journal of islamic nursing. Vol 3.

Nurmalia, D. (2013). Pengaruh program mentoring terhadap penerapan budaya keselamatan pasien. Jurnal Manajemen Keperawatan, 1(2), 79-88.

Simamora, R. H., \&Fathi, A. (2019). The Influence Of Training Handover Based SBAR Communication For Improving Patients Safety. Indian journal of public health research \& development, 10(9), 1280-1285.

Yennike, T.H. (2015). Budaya keselamatan pasien di ruang rawat inap rumah sakit x kabupaten jember Jurnal Ikesma. Vol 11. Hal 53-58.

Yeni, Y,\& Maswarni. (2019). Budaya keselamatan pasien pada perawat di instalasi perawatan intensive rsud arifin achmad provinsi riau. Jurnal Keperawatan Priority. Vol 2. Hal 113117.

Yulia, Y., \& Hasbullah, T. (2015). Faktor-Faktor yang Berhubungan dengan Budaya Keselamatan Pasien di Rumah Sakit Karya Bhakti Pratiwi Bogor Tahun 2015. Jurnal Arsi. Vol 4. Hal 98-100 